\title{
Investigation of the Possible Association between Human Cytomegalovirus and Pterygium Development
}

Mishar Kelishadi (PhD Candidate) Laboratory Sciences Research Center, Golestan University of Medical Science, Gorgan, Iran; and Department of Virology, Pasteur Institute of Iran, Tehran, Iran

Mandana Kelishadi (MD) Department of Ophthalmology, $5^{\text {th }}$ Azar Hospital, Gorgan, Iran

G.Hossein Ashrafi (PhD) Kingston University London, Cancer Theme, School of Life Science, Pharmacy and Chemistry, SEC Faculty, Kingston upon Thames, KT12EE, London, UK

Alijan Tabarraei (PhD) Infectious Diseases Research Center, Golestan University of Medical Sciences, Gorgan, Iran

Corresponding author: Alijan Tabarraei

Tel: $+98-1732422652$

Email: alijant@yahoo.com

Address: Infectious diseases research centre, Department of microbiology, Golestan University of Medical

Received: 22 Jul 2018

Revised: 07 Nov 2018

Accepted: 20 Nov 2018

\section{(c) (i) (8)}

This work is licensed under a Creative

Commons Attribution 4.0 License.

\section{ABSTRACT}

Background and Objectives: Pterygium is a common ocular surface lesion that manifest as wing-shaped, benign conjunctival growth, which can extend onto the corneal surface. Presence of some oncogenic viruses in pterygium and the neoplastic nature of the lesion led us to the postulated involvement of the viruses in the etiology of pterygia. The aim of this study was to evaluate prevalence and possible role of human cytomegalovirus (HCMV) in the formation of pterygia.

Methods: Fifty pterygium specimens and 10 normal conjunctival biopsy specimens (controls) were investigated by polymerase chain reaction using primers specific for the highly conserved regions of major capsid protein gene of HCMV. Data were analyzed using SPSS statistical software (IBM SPSS Statistics 18; IBM Corporation, ISA) at significance level of 0.05 .

Results: The HCIV DNA was detected in seven (14\%) patients with pterygium but in none of the control subjects. All subjects were $\beta$-globin positive.

Conclusion: Given the results, direct involvement of HCVV in the development of pterygium seems less probable, thus suggesting that other agents might be involved in the multistep process of the disease.

Keywords: Human Cytomegalovirus, Pterygium, Polymerase Chain Reaction.

This paper should be cited as: Kelishadi M, Kelishadi M, Ashrafi GH, Tabarraei A[Investigation of the Possible Association between Human Cytomegalovirus and Pterygium Development ]. mljgoums. 2019; 13(4):1-4 


\section{INTRODUCTION}

Pterygium is a common ocular surface lesion characterized by wing-shaped, vascular and fleshy growth that can extend onto the corneal surface (1). Cell proliferation and angiogenesis induction, interference with signaling pathways and resistance to apoptosis are hallmarks of pterygium, which support the neoplastic nature of this lesion (2-6).

Long-term exposure to ultraviolet-light, low humidity and dust are thought to be main causes of pterygium. Recurrence is one of the most frequent (as high as 46\%) problems after tissue excision (2). Recent studies suggest that potentially oncogenic viruses such as human papillomavirus (HPV), Epstein-Barr virus and herpes simplex virus may also be involved in the pathogenesis of pterygium $(7,8)$. Although presence of a large population of HPV in pterygium has been reported by several studies, many have failed to detect HPV DNA in tissue specimens. The role of viruses in the progression of pterygium is not completely elucidated $(5,9)$. Many have demonstrated that human cytomegalovirus (HCMV) infection may promote neoplasia (10). HCMV is a widespread human pathogen that is generally asymptomatic in healthy children and adults. Most normal individuals become infected early in life, which usually leads to life-long persistence. However, reactivation of the latent virus might trigger cellular damage in infected organs that can lead to numerous neoplastic diseases, including prostatic carcinoma, breast cancer, colorectal adenocarcinoma, cervical cancer, Kaposi's sarcoma, medulloblastoma, glioblastoma and neuroblastoma $(7,11,12)$.

The expression of specific HCMV genes such as IE1 and IE2 with oncogenic potential, can lead to the postulated involvement of the virus in the etiology of pterygium (11). In this study, we investigated association of HCMV infection with pterygium development.

\section{MATERIALS AND METHODS}

This cross-sectional study was performed at the Department of Virology of the Golestan University of Medical Sciences, Gorgan, Iran. The study received approval from the Ethics Committee of the university. Fifty human biopsy specimens of pterygium were collected as case and 10 conjunctival biopsy specimens of individuals (without characteristics of pterygium) who were undergoing cataract surgery were collected as controls. All subjects were selected from patients referred to the $5^{\text {th }}$ Azar Hospital in Gorgan (Iran) between February 2011 and May 2014.

Inclusion criteria included having primary or recurrent pterygium in one or both eyes. Those with ocular disease other than pterygium or its sequelae (after-effects), including neoplasia (uncontrolled overgrowth) were excluded from the study.

Specimens were cut into sections, which were later examined histopathologically to confirm the diagnosis. The samples were stored at -70 ${ }^{\circ} \mathrm{C}$ until processing.

Viral DNA was extracted from the samples using QIAamp DNA Mini kits (Qiagen, USA) according to the manufacturer's instructions. Target sequences were amplified for the presence of CMV-DNA using the following primers: 5'-GAGCGCGTCCACAAAGTCTA3' and 5'-GTGATCCGACTGGGCGAAAA-3' (264bp) that are specific for the highly conserved regions of major capsid protein (MCP) gene of HCMV (NCBI Reference Sequence: M25411.1) (13). Polymerase chain reaction (PCR) was carried out in a $25 \mu 1$ reaction volume containing $1 \mu \mathrm{l}$ extracted DNA sample (1.5-2.5 $\mu \mathrm{g}), 10$ pmol of each primer, $2.5 \mathrm{U}$ Taq DNA polymerase (Genet Bio [A type]), $0.1 \mathrm{mM}$ dNTP, $2.5 \mathrm{mM} \mathrm{MgCl}_{2}$ and $5 \mu \mathrm{l}$ 10X PCR reaction buffer using a Peq Lab thermal cycler (Primus Advanced 96 thermal cycler). All standard precautions were followed to prevent PCR contamination, and positive and negative controls were included in each run. For samples with low or undetectable concentrations of CMV DNA, 1 $\mu \mathrm{l}$ from each reaction solution was reamplified in a second round of PCR with the same primers.

Cycling conditions were as follows: $5 \mathrm{~min}$ at $95{ }^{\circ} \mathrm{C}, 35$ cycles of $40 \mathrm{~s}$ at $94{ }^{\circ} \mathrm{C}, 20 \mathrm{~s}$ at $50{ }^{\circ} \mathrm{C}$ and $20 \mathrm{~s}$ at $72{ }^{\circ} \mathrm{C}$. Ten pmol/ $\mu \mathrm{l}$ of each $\beta$ globin primer GAAGATGGTGATGGGATTTC-3' and 5'GAAGGTGAAGGTCGGAGTC-3') were used to analyze the quality of the target DNA and to exclude false negative results in a $25 \mu \mathrm{l}$ reaction volume containing $5 \mu \mathrm{l}$ extracted DNA $(500 \mathrm{ng} / \mathrm{ml}), 0.1 \mu \mathrm{l}$ of each primers, 0.3 U Taq DNA polymerase (Genet Bio [A type]), $0.5 \mu \mathrm{l} 10 \mathrm{mM}$ dNTP, $2 \mu 1 \mathrm{MgCl}_{2}(25 \mathrm{mM})$ and 
$5 \mu \mathrm{l}$ 10X PCR reaction buffer. PCR was performed for $5 \mathrm{~min}$ at $95{ }^{\circ} \mathrm{C}$, followed by 35 cycles of $30 \mathrm{~s}$ at $94{ }^{\circ} \mathrm{C}, 30 \mathrm{~s}$ at $60^{\circ}, 30 \mathrm{~s}$ at 72 ${ }^{\circ} \mathrm{C}$ and $7 \mathrm{~min}$ at $72{ }^{\circ} \mathrm{C}$. The PCR products were analyzed on a $2 \%$ agarose gel stained with ethidium bromide.

Prevalence was calculated at $95 \%$ confidence interval. The chi-square test or Fisher's exact test was performed to evaluate distribution of characteristics associated with CMV infection. All statistical tests were performed at significance level of 0.05 . All analyses were performed with SPSS statistical software (IBM SPSS Statistics 18; IBM Corporation, USA).

\section{RESULTS}

Of 50 patients examined in this study, 20 were male and 30 were female. Mean age of the patients was $61.1 \pm 16.9$ years (age range: 22-85 years). The control group consisted of six males and four females with mean age of $58.9 \pm 15.5$ years (age range: $19-70$ years).

Thirteen patients had bilateral pterygia. Fortytwo pterygia were primary lesions and eight were postoperative recurrent. In the clinical evaluation for grading the severity of pterygia, 14 (28\%) were atrophic/grade1; 17 (34\%) were intermediate/grade2; and 19 (38\%) were fleshy/grade3. Two cases (4\%) had a positive family history for pterygium. Five cases (10\%) had a history of outdoor activities and seven cases $(14 \%)$ had a history of smoking.

The HCMV DNA was detected in seven (14\%) patients with pterygium but not in the control individuals. Both groups were positive for the $\beta$-globin gene. Among the seven subjects who were HCMV-positive, two $(28.57 \%)$ were male; five $(71.43 \%)$ were female; all had primary lesions (three cases in the right eye and four in the left eye); four $(57.14 \%)$ had atrophic/grade 1 lesions; and three $(42.86 \%)$ had fleshy/grade 3 lesions. Moreover, two cases $(28.57 \%)$ had a positive family history for pterygium, but none had a history of outdoor activities.

The prevalence of HCMV was higher in patients aged 65-85 years. There was no statistically significant correlation between pterygium and presence of $\mathrm{HCMV}(\mathrm{P}=0.25)$.

\section{DISCUSSION}

The possible relationship between HCMV infection and neoplasia has been investigated for decades. Although CMV is common in the human population, it is generally not regarded as an oncogenic virus. However, increasing evidence implies that HCMV infection is associated with a number of malignancies (14). Due to tendency of HCMV to produce persistent infections, an etiological association between the infection and neoplasia remains controversial (15).

We found the HCMV DNA in $14 \%$ of the tissue specimens from patients with pterygium. This might mean that HCMV can act as a chronic indirect tumor virus that increases cell proliferation until forming a benign tumor over decades of infection $(7,10)$. In addition, the transformation might occur through a "Hitand-Run" mechanism by the HCMV oncogenes (15).

The prevalence of HCMV-DNA in patients with pterygium was $40 \%$ in a study by Spandidos et al. (3) and $50 \%$ in a study by Simbiri et al. (14), which are higher than the rate observed in our study. It is believed that the prevalence of HCMV infection in the tissue sections may be underestimated when using other highly sensitive detection techniques, such as immunohistochemistry and in-situ hybridization $(14,16)$.

Below, we discuss how HCMV may induce neoplastic transformation of cells and development of tumor-like lesions such as pterygia (conjunctival neoplasia).

1. HCMV latency and persistence along with other environmental factors may be crucial for initiating cell transformation $(10,14,17)$, which leads to a selection of novel HCMV variant that may be unique and with oncogenic capacity. In vitro studies elucidate that HCMV transforming genes, particularly mtrII, are responsible for the tumorigenic phenotype in a variety of mammalian cells (15).

2. Given the ubiquitous nature of HCMV, one can speculate that the IEI and IE2 gene products might be mutagenic and cooperate/interact with other viral oncoproteins including adenovirus E1A and E1B, HPV E6 and E7, or even tumor necrosis factor in fibroblasts, smooth muscle cells or endothelial cells in order to block apoptosis or to transform cells $(11,18-20)$.

3. Peden et al. found host/virus DNA homology and suggested a mechanism through which HCMV may integrate into the host cell and transform cells. HCMV-encoded proteins such as IE1, IE2, IE-72 and US28 have potent 
oncomodulatory properties that can enhance cellular gene activity and deregulate important functional cell-encoded proteins $(7,15,17$, $18)$.

\section{CONCLUSION}

Given the low prevalence (14\%) of HCMV in patients with pterygium, we speculate that a direct involvement of HCMV in the development of pterygium seems less probable, thus suggesting that other agents might be involved in the multistep process of the disease.

\section{ACKNOWLEDGEMENTS}

We would like to thank the Laboratory Sciences Research Center of the Golestan

\section{REFERENCES}

1. Sjö NC, Von Buchwald C, Prause JU, Norrild B, Vinding T, Heegaard S. Human papillomavirus and pterygium. Is the virus a risk factor? British journal of $\begin{array}{llll}\text { ophthalmology. } \quad 2007 ; & 91(8): & 1016-8 .\end{array}$ doi: 10.1136/bjo.2006.108829.

2. Yaisawang S, Piyapattanakorn P. Role of postoperative topical corticosteroids in recurrence rate after pterygium excision with conjunctival autograft. J Med Assoc Thai. 2003; 86 (Suppl 2): S215-23.

3. Spandidos D, Sourvinos G, Kiaris H, Tsamparlakis J. Microsatellite instability and loss of heterozygosity in human pterygia. Br J Ophthalmol. 1997; 81(6): 493-6.

4. Rodrigues F, Arruda J, Silva R, Moura K. TP53 gene expression, codon 72 polymorphism and human papillomavirus DNA associated with pterygium. Genet Mol Res. 2008; 7(4): 1251-8.

5. Detorakis ET, Sourvinos G, Spandidos DA. Detection of herpes simplex virus and human papilloma virus in ophthalmic pterygium. Cornea. 2001; 20(2): 164-7.

6. Gallagher M, Giannoudis A, Herrington C, Hiscott P. Human papillomavirus in pterygium. Br J Ophthalmol. 2001; 85(7): 782-784. doi: 10.1136/bjo.85.7.782

7. Alibek K, Kakpenova A, Baiken Y. Role of infectious agents in the carcinogenesis of brain and head and neck cancers. Infect Agent Cancer. 2013; 8(1): 7. doi: 10.1186/1750-9378-8-7.

8. Vishnu P, Aboulafia DM. The Oncogenicity of Human Cytomegalovirus. NM a $S$ Patricia Price ed Manifestations of Cytomegalovirus Infection InTech. 2013. DOI: $10.5772 / 55051$.

9. Kelishadi M, Moradi A, Bazouri M, Tabarraei A. Is Epstein-Barr virus associated with pterygium? J Gorgan Univ Med Sci. 2014; 16(3): 117-121.

10. Michaelis M, Doerr HW, Cinatl J. The story of human cytomegalovirus and cancer: increasing evidence and open questions. Neoplasia. 2009; 11(1): 1-9.

11. Shen Y, Zhu H, Shenk T. Human cytomegalovirus IE1 and IE2 proteins are mutagenic and mediate "hitand-run" oncogenic transformation in cooperation with the adenovirus E1A proteins. Proceedings of the National Academy of Sciences. 1997; 94(7): 3341-5.
University of Medical Sciences for the continuous encouragement during this study. We also gratefully acknowledge the Department of Ophthalmology of the $5^{\text {th }}$ Azar Hospital for providing the valuable tissue specimens.

\section{CONFLICT OF INTEREST}

The authors declare that there is no conflict of interest regarding the publication of this article.

\section{Funding/Support}

This project was supported by the Laboratory Sciences Research Center, Golestan University of Medical Sciences (Grant No: 921120194).

12. Sutcliffe S, Viscidi RP, Till C, Goodman PJ, Hoque AM, Hsing AW, et al. Human papillomavirus types 16, 18 , and 31 serostatus and prostate cancer risk in the Prostate Cancer Prevention Trial. Cancer Epidemiol Biomarkers Prev. 2010; 19(2): 614-8. doi: 10.1158/10559965.EPI-09-1080.

13. Saygun I, Yapar M, Özdemir A, Kubar A, Slots J. Human cytomegalovirus and Epstein-Barr virus type 1 in periodontal abscesses. Oral Microbiol Immunol. 2004; 19(2): 83-7.

14. Simbiri KO, Murakami M, Feldman M, Steenhoff AP, Nkomazana O, Bisson G, et al. Multiple oncogenic viruses identified in Ocular surface squamous neoplasia in HIV-1 patients. Infect Agent Cancer. 2010; 5(6): 175093. doi: 10.1186/1750-9378-5-6.

15. Doniger J, Muralidhar S, Rosenthal LJ. Human cytomegalovirus and human herpesvirus 6 genes that transform and transactivate. Clinical microbiology reviews. 1999; 12(3): 367-82.

16. Chalkia AK, Spandidos DA, Detorakis ET. Viral involvement in the pathogenesis and clinical features of ophthalmic pterygium (Review). Int J Mol Med. 2013; 32(3): 539-543.

17. Macnab JC. Herpes simplex virus and human cytomegalovirus: their role in morphological transformation and genital cancers. Journal of general virology. 1987; 68(10): 2525-50. DOI: 10.1099/00221317-68-10-2525

18. Cinatl J, Cinatl J, Vogel J-U, Kotchetkov R, Driever $\mathrm{PH}$, Kabickova $\mathrm{H}$, et al. Persistent human cytomegalovirus infection induces drug resistance and alteration of programmed cell death in human neuroblastoma cells. Cancer research. 1998; 58(2): 36772.

19. Zhu H, Shen Y, Shenk T. Human cytomegalovirus IE1 and IE2 proteins block apoptosis. Journal of virology. 1995; 69(12): 7960-70.

20. Kelishadi M, Kelishadi M, Moradi A, Javid N, Bazouri M, Tabarraei A. human adenoviruses role in ophthalmic pterygium formation. Jundishapur journal of microbiology. 2015;8(4): e16871. 